\title{
Krigets fångar och änglar: Svenska hjälparbetare under första världskriget
}

\author{
Per Allan Olsson \\ Lund: Historiska media 2018 \\ 331 sidor. ISBN 97891754575994
}

Recenserad av Ingmar Oldberg [associerad forskare, Utrikespolitiska institutet, ingmar.oldberg@gmail.com]

Mycket har skrivits om första världskriget och dess politiker och militärer, inte minst vid jubileerna hundra år efteråt, men mycket mindre om offren, krigsfångarna och hjälparbetarna. Den här boken handlar om det svenska Röda korsets (RK) insatser i Ryssland bland de två miljonerna krigsfångar, främst från Tyskland och Österrike-Ungern, som spreds till läger över hela landet. Eftersom Sverige var neutralt i kriget, vände sig Tyskland och Ryssland 1915 till Sverige för att utväxla och få fram hjälp till sina respektive krigsfångar. Över tusen järnvägsvagnar med förnödenheter gick genom Sverige från Trelleborg till Haparanda för vidaretransport på ryska järnvägar. Inalles 77 svenska delegater arbetade på plats i Ryssland. Många var kvinnor, oftast ur överklassen, som sökte sig ut i arbetslivet som volontärer. De var tysktalande och anklagades ofta lokalt för tyskvänlighet och spioneri, många arresterades och några dödades. Detta blev Sveriges första stora humanitära insats utomlands och inledde en tradition som fortsatt till våra dagar.

Insatserna i Ryssland har tidigare skildrats i skrifter av några RK-delegater. Mest känd är Elsa Brändströms Bland krigsfångar $i$ Ryssland och Sibirien från 1921. På senare tid har slavisten Lars Kleberg forskat om sin avlägsne släkting, ingenjören John Klebergs öde (Svenska dagbladet, 24 januari 2019).

Per Allan Olsson, som själv arbetat för Röda korset, koncentrerar sig i denna bok på friherrinnan Anna Linders och akademikern Sven Hedbloms erfarenheter och bygger på deras rapporter, brev, dagböcker och anteckningar som samlats i olika arkiv, samt på memoarer och senare forskning. Han har samarbetat med ryska historiker men redovisar inga ryska källor. (Ryska namn är ofta felstavade.)

Boken är lite svår att genrebestämma. Den är inte strikt vetenskaplig, eftersom den saknar fotnoter och gränsen mellan källornas uppgifter och författarens tillägg ofta är vag. Olsson kallar boken för en berättelse och en rekonstruktion, där han lagt in sina egna tolkningar av huvudpersonernas känslor och stämningar utifrån källorna. Boken är en dramatisk, nästan spännande, men även informativ skildring 
av hjälpverksamheten i Ryssland från hösten 1915 till 1920 - under tsartid, revolutionsåret 1917 och inbördeskriget. Det märks att mycket forskning ligger bakom. Kapitlen om huvudpersonerna varvas kronologiskt och speglar ett komplicerat storpolitiskt händelseförlopp.

Bokens ena huvudperson, Anna Linder, umgicks i det svenska hovet, som stödde Tyskland i kriget men också den humanitära insatsen, och ägnade sig redan före kriget åt välgörenhet i Sverige och Tyskland. Hon och Elsa Brändström, dotter till Sveriges generalkonsul i Petrograd, blev ledande i den svenska RK-insatsen i Ryssland.

Olsson skildrar hur den första delegationen med Linder och Hedblom i oktober 1915 lämnar Sverige och reser österut ända till Tjita för att fördela hjälpsändningar till olika fångläger. De förfäras över de hemska förhållandena med hård köld, usel mat och sjukdomar. Våren 1916 omplaceras Linder till Totskoje nära Volga, ett av de värsta lägren, där fläcktyfusen grasserar. På hösten förflyttas Linder till Samara vid Volga, som blir hennes bas i fyra år.

Under åren inträffar flera förändringar. Tsaren beslutar att krigsfångarna ska sättas $i$ arbete för att ersätta de ryssar som sänds till fronten. 70000 fångar skickas till byggandet av en järnväg från Petrograd till Kolaviken som behövs för att motta hjälp från de allierade när andra hamnar i väst blockerats. Problemen med kyla, smuts och mat är fruktansvärda, 75-90 procent drabbas av skörbjugg och 25000 dör. Då Tyskland får vetskap om problemen och protesterar, beordrar tsaren evakuering av de resterande krigsfångarna, de flesta svårt sjuka, söderut till Turkestan via Samara. Linder och John Kleberg engageras i detta.

Röda korset får vidare ansvar för några av de 300000 civilfångarna, mest tyskar och österrikare, som bott och arbetat i Ryssland men vid krigsutbrottet arresterats och internerats. Linder kan dock använda några av dem i hjälparbetet. Hösten 1916 delas krigsfångarna upp i nationaliteter och de som kunde ha sympatier för ententen skiljs ut. Tjeckerna får bilda egna förband för att kämpa för en självständig stat.

Februarirevolutionen i mars 1917 underlättar hjälparbetet och hoppet om separatfred växer. Men då kriget åter flammar upp under sommaren, intensifieras propagandan mot Tyskland och dess krigsfångar, och nya, strängare regler införs i lägren.

Efter bolsjevikkuppen i Petrograd i november 1917 blir Linder vittne till hur en sovjet tar makten i Samara under Valerian Kujbysjev (sedermera ledande ekonom under Stalin, som gav staden hans namn), och den begynnande röda terrorn med avrättningar och plundring. Borgare sätts att sopa gator och rengöra toaletter, kvinnorna tvingas ut i arbetslivet och fängelsefångar blir poliser. Krigsfångarna släpps fria, men får ingen hjälp av sovjetmakten och trängs med hemvändande soldater på sjukhusen.

I det begynnande inbördeskriget 1918 försöker bolsjevikerna värva krigsfångar till Röda armén med löften om mat och sold, och i Samara hålls den första revolutionära krigsfångekongressen, som agiterar mot andra krigsfångar och även mot de svenska hjälparbetarna. Efter Brest-Litovsk-freden i mars reser många tyska och 
ungerska fångar hemåt, vilket underlättas när Tyskland tar kontroll över Ukraina. Béla Kun, som Olsson kunde ha nämnt, blir ett år senare ledare för Ungerska sovjetrepubliken.

De 40000 stridsvana tjeckiska legionärerna, som tidigare fått fri lejd till Vladivostok för att den vägen ta sig till västfronten och fortsätta kriget, kommer snart i konflikt med bolsjevikerna, som enligt Brest-Litovsk-avtalet med Tyskland måste avväpna dem. Linder stöter på en tjeck vid namn Jaroslav Hasek, sedermera författare till boken om den tappre soldaten Svejk. Hon får uppleva hur tjeckerna i juni 1918 erövrar Samara och hjälper socialistrevolutionärerna att upprätta en kommitté, som utnämner sig till landets enda lagliga regering. Tjeckerna erövrar snart hela järnvägen bort till Vladivostok och hindrar alla transporter västerut. De ser svenskarna som Tysklands hantlangare och arresterar en hjälpdelegation med Elsa Brändström på väg till Sibirien. I Omsk, där tsaramiralen Koltjak i november 1918 utropar sig till hela Rysslands härskare och förföljer alla motståndare, får svenskarna dock besöka fånglägren med stöd av britter, som kommit österifrån.

Även efter Röda arméns återerövring av Samara i oktober 1918 och fram till Koltjaks förlust av Omsk i november 1919 fortsatte Linders respektive Brändströms hjälpverksamhet. Båda återkom helbrägda till Stockholm i juni 1920.

Ett tragiskt öde drabbade däremot John Kleberg och bokens andra huvudperson, Sven Hedblom. Kleberg mördades i januari 1919 i Tasjkent av bolsjevikerna, anklagad för samröre med fienden. Hedblom, som stationerats i Chabarovsk 1916, försökte utverka nödhjälp från USA, Storbritannien och Frankrike, som intervenerat i Sibirien för att stödja tjeckerna och återupprätta en östfront mot Tyskland. Han hamnade dock i en komplicerad maktkamp mellan dessa stater, Japan, bolsjevikerna och kosackförband i Manchuriet. Med stöd av Japan intog Ussuri-kosackerna Chabarovsk i september 1918, plundrade RK:s kontor, grep och avrättade Hedblom. Enligt Olsson fick han ingen hjälp från svenska konsulat - om den nu var möjlig. Först 1921-1922 kunde huvuddelen av fångarna i Sibirien utskeppas från Vladivostok med amerikansk hjälp. Då pågick redan en svältkatastrof i Samara-området, som krävde nya hjälpinsatser (koordinerad av Fridtjof Nansen).

Trots Olssons ibland alltför personnära och "hoppiga» framställning övertygar han om att det svenska Röda korset gjorde stora insatser för krigsfångarna och räddade många liv. 400000 dog ändå. Han visar att Anna Linder spelade en viktig roll vid sidan av den mer namnkunniga Elsa Brändström. Han lyfter även fram Sven Hedblom ur glömskan. Detta är också en insats. 